\title{
Self-Seeding Warm-Season Legumes for Low-Input Forage Production in the Southern Great Plains of the USA
}

\author{
Paul W. Bartholomew \\ USDA-ARS Grazinglands Research Laboratory, El Reno, OK, USA \\ Email: paul.bartholomew@ars.usda.gov
}

Received 5 August 2014; revised 15 September 2014; accepted 15 October 2014

Copyright (C) 2014 by author and Scientific Research Publishing Inc.

This work is licensed under the Creative Commons Attribution International License (CC BY). http://creativecommons.org/licenses/by/4.0/

(c) (i) Open Access

\section{Abstract}

In the southern Great Plains (SGP) of the USA warm-season legumes can improve the quality of available forage in pasture systems based on perennial warm-season grasses. Legumes that persist through self-seeding may be especially useful in low-input systems where resources for annual replanting are limited. The productivity and capacity for self-seeding of Korean lespedeza (Kummerowia stipulacea [Maxim.] Makino) and Verano stylo (Stylosanthes hamata [L.] Taub.) were tested in controlled environment and in field plots in the SGP. At similar levels of accumulated temperature, germination of Korean lespedeza was unaffected by day/night temperature regimes between $15 / 15^{\circ} \mathrm{C}$ and $30 / 15^{\circ} \mathrm{C}$. In contrast, at similar accumulated temperatures, germination of Verano stylo increased with higher daytime maximum temperature up to $30^{\circ} \mathrm{C}$. Seedling growth of both species was reduced by shading, in proportion to the reduction in photosynthetic flux density. Growth of Korean lespedeza up to five weeks after emergence was greatest under a $22.5 / 7.5^{\circ} \mathrm{C}$ temperature regime but that of Verano stylo was greatest at $30 / 15^{\circ} \mathrm{C}$. In the field Korean lespedeza was a prolific seeder and productive of forage though susceptible to significant loss of leaf material in late summer and fall. Verano stylo did not reseed effectively and was not a reliable forage producer.

Keywords

Korean Lespedeza, Verano Stylo, Self-Seeding, Forage

\section{Introduction}

Feed quality of unimproved warm-season pastures in the Southern Great Plains (SGP) can be improved by in- 
clusion of legumes in the system [1] [2]. Annual forage legumes may be productive during the summer months [3] [4], but their adoption by low-input farmers is often constrained by limited resources for cultivation and sowing. The use of perennial crops could eliminate the need for regular replanting, but lack of persistence of legumes is a widely-reported problem [5]. Self-reseeding annual legumes may have a role to play in low-input systems if, once established, they can be managed to produce both forage and sufficient seed to enable re-establishment in the following growing season. Korean lespedeza (Kummerowia stipulacea [Maxim.] Makino) is recognized as a useful summer annual legume forage that has the capacity to self-reseed [6] [7], and it has been used with some success in the SGP as a relay crop following a winter cereal [8]. Verano stylo (Stylosanthes hamata [L.] Taub.) has proven to be productive and persistent in semi-arid zone pasture systems in Australia and west Africa [9]. In central Florida S. hamata has demonstrated rapid maturity and a capacity for seed production [10] but it is untested in the SGP where successful re-establishment of annual legumes is likely to be constrained by low temperatures early in the growing season and by competition with regrowing warm-season grass as the season advances. The objectives of this work were to assess the capacity of lespedeza and stylo for growth under low-temperature and limited light input, in controlled and field environments, to evaluate their potential for use as summer forages in low input livestock production systems in the SGP.

\section{Materials \& Methods}

\subsection{Germination Responses to Temperature}

The germination of hulled seeds of lespedeza and unhulled seeds of stylo (as sown in the field), together with manually hulled seeds of stylo, was observed in incubator studies under a range of day and night temperature regimes. Twenty five seeds of each type were germinated in petri dishes on filter paper moistened with $10 \mathrm{~mL}$ of deionized water under day/night temperatures of $30 / 15$, $22.5 / 15$, $15 / 15$ or $22.5 / 7.5^{\circ} \mathrm{C}$. Each treatment was repeated four times.

\subsection{Effects of Light and Temperature on Lespedeza and Stylo Seedling Growth}

The effect of temperature and light-input regimes on seedling growth of lespedeza and stylo was studied in a growth chamber (Controlled Environments Inc., Pembina, ND). Individual seedlings of lespedeza and stylo were grown in $155 \mathrm{~mL}$ pots ("Conetainers" ${ }^{\circledR}$, Stuewe \& Co. Corvallis, OR) in potting soil (Baccto [Michigan Peat Co., Houston TX] consisting $840 \mathrm{~g} \cdot \mathrm{kg}^{-1}$ reed sedge peat $+160 \mathrm{~g} \cdot \mathrm{kg}^{-1}$ sand and perlite). Five replicate seedlings were grown under each temperature and light treatment. Watering was made through uniform applications of $10 \mathrm{~mL}$ of deionized water to each plant, at a frequency sufficient to keep the surface soil moist. Plants were subject to a $13 \mathrm{~h}$ light and $11 \mathrm{~h}$ dark regime under day/night temperature regimes of $30 / 15$ or $22.5 / 7.5^{\circ} \mathrm{C}$ at photosynthetic photon flux densities of 250 (full light, FL) or 90 (shade, $\mathrm{SH}$ ) $\mu \mathrm{E} \cdot \mathrm{m}^{2} \cdot \mathrm{sec}^{-1}$, measured at the top of the plant canopy. The reduced light treatment was achieved by shading seedlings under shade cloth with nominal $75 \%$ exclusion. Destructive harvests were made at 2, 3, 4 or 5 weeks post-emergence to assess the effect of treatments on seedling growth. At each harvest seedlings were extracted from soil by washing under running water and top growth was separated from roots at the crown. The total leaf area of each seedling was estimated by passing detached leaf laminae through a LI-3100 leaf area meter (LI-COR, Lincoln, NE). Seedling top and root growth were subsequently dried at $60^{\circ} \mathrm{C}$ to measure seedling component and total DM.

\subsection{Forage Production and Seeding Capacity of Lespedeza and Stylo}

Field experiments were undertaken in 2001 and 2002 at a site $6 \mathrm{~km} \mathrm{~S}$ of Langston, OK (35 53' N, 97 $17^{\circ} \mathrm{W}$ ) that had been maintained as unimproved warm-season pasture for over 15 years. Soil was a Coyle series loam (fineloamy siliceous thermic Udic Arguistoll) and analysis showed a pH of 6.1, nitrate-nitrogen of $9 \mathrm{~kg} \cdot \mathrm{ha}^{-1}$, phosphorus index (Mehlich 3) of 10 and a potassium index of 226 in the upper $15 \mathrm{~cm}$ of the soil profile. Following seedbed preparation by rotatiller, Korean lespedeza was sown at $20 \mathrm{~kg} \cdot \mathrm{ha}^{-1}\left(1255\right.$ seeds per $\left.\mathrm{m}^{2}\right)$ in both years and Verano stylo was sown at $10 \mathrm{~kg} \cdot \mathrm{ha}^{-1}$ in 2001 and $11 \mathrm{~kg} \cdot \mathrm{ha}^{-1}$ in 2002 (359 and 395 seeds per m², respectively). Sowing was achieved by broadcasting in all cases. Seeds were treated with commercial Bradyrhizobium inoculant immediately prior to sowing in each year. In 2001 lespedeza was sown in early May, and stylo in early June. In 2002 both lespedeza and stylo were sown in early April. Harvests for DM yield estimation were taken at two-week intervals from mid-July to end October in each year, for a total of eight sample dates, each replicated 
three times. Sown plot size was $1.21 \times 6.01 \mathrm{~m}$ and an area of $0.86 \times 6.01 \mathrm{~m}$ was cut for yield estimation, using a sickle-bar mower (Troybilt, Troy, NY) set to a stubble height of $0.05 \mathrm{~m}$. The material harvested from each plot was weighed fresh in the field and a sample of approximately $200 \mathrm{~g}$ of fresh material was taken for hand-separation of sown warm-season legume, grass or forb. Separated material was dried at $60^{\circ} \mathrm{C}$ for 48 hours and weighed for estimation of component DM and sample DM content. Losses of leaf material by lespedeza and stylo were estimated by collection of shed leaves within a $0.15 \times 0.15 \mathrm{~m}$ quadrat. Self-seeding capacity was measured after the final harvest in each year by collection of seed deposited on the soil surface, within a $0.15 \times 0.15 \mathrm{~m}$ quadrat, using a hand-held vacuum cleaner. Following cropping with lespedeza in 2001 and 2002, the emergence of self-sown seedlings was counted within three $0.15 \times 0.15 \mathrm{~m}$ quadrats on each plot in early April in each of the following years.

\subsection{Statistical Analysis}

Statistical analysis was made using Genstat procedures [11] to fit regression lines to germination data and for ANOVA of controlled environment and field experiments.

\section{Results}

\subsection{Germination Responses to Temperature}

When expressed on a growing degree day (GDD) timescale (accumulated mean daily temperature above $0^{\circ} \mathrm{C}$ ), germination rate in lespedeza was not significantly changed by temperature regimes within the range 15/15 to $30 / 15^{\circ} \mathrm{C}$ (Figure 1(a)). Germination of stylo in response to temperature treatment was much more variable than that of lespedeza. The overall germination percentage of stylo at a maximum temperature of $15^{\circ} \mathrm{C}\left(15 / 15^{\circ} \mathrm{C}\right)$ was only $3 \%$ with unhulled seed and $7 \%$ with hulled seed. An increase in daytime maximum temperature to $22.5^{\circ} \mathrm{C}$, at a daily mean temperature of $15^{\circ} \mathrm{C}\left(22.5 / 7.5^{\circ} \mathrm{C}\right)$, resulted in a large increase in overall germination percentage with both hulled and unhulled stylo. In unhulled stylo, an increase in temperature to a daily mean of $22.5^{\circ} \mathrm{C}$ $\left(30 / 15^{\circ} \mathrm{C}\right)$ produced further increases in overall germination percentage (Figure 1(b)). Germination rate in hulled stylo, at a daily high temperature of $22.5^{\circ} \mathrm{C}$ or above, was less affected by increase in mean temperature, than in unhulled stylo (Figure 1(c)).

\subsection{Effects of Light and Temperature on Lespedeza and Stylo Seedling Growth}

Under a temperature regime of $30 / 15^{\circ} \mathrm{C}$, growth of lespedeza and stylo seedlings was similar within light input treatment (Figure 2(d), Figure 2(e), Figure 2(f)). Seedling leaf area and rate of DM accumulation were reduced $(\mathrm{P}<0.05)$ in both species under reduced light, but there was no difference in response between species. Under a temperature regime of $22.5 / 7.5^{\circ} \mathrm{C}$ lespedeza grew significantly faster than stylo in both full and reduced light (Figure 2(a), Figure 2(b), Figure 2(c)). Stylo, in contrast, grew significantly faster at $30 / 15^{\circ} \mathrm{C}$ than at 22.5/ $7.5^{\circ} \mathrm{C}$, but even at the higher average temperature, under similar light input, its growth rates were lower than those of lespedeza at temperatures of $22.5 / 7.5^{\circ} \mathrm{C}$. In both species the relative seedling productivity was similar to the change in light input.

\subsection{Seasonal Distribution of Lespedeza and Stylo Production}

In 2001 and 2002 respectively, total annual rainfall was 88\% and 102\% of the 30 -year average of $937 \mathrm{~mm}$. In 2002 the distribution of rainfall up to July more closely matched that of the long-term average than did that of 2001; late-summer and fall rainfall in 2002 was greater than both 2001 and the 30yr mean for the same period (Figure 3(a)). Mean daily temperatures were higher in 2001 than 2002 through spring and summer, and in both years were greater than the $30 \mathrm{yr}$ average (Figure 3(b)). Lespedeza established well in both years, with a mean established plant stand of $435 \mathrm{pl} \cdot \mathrm{m}^{-2}$ in 2001 and $226 \mathrm{pl} \cdot \mathrm{m}^{-2}$ in 2002. Stylo establishment was slow and established plant density reached only $30 \mathrm{pl} \cdot \mathrm{m}^{-2}$ in 2001 and $17 \mathrm{pl} \cdot \mathrm{m}^{-2}$ in 2002. Productivity reflected the establishment performance, with a maximum yield of lespedeza of $2030 \mathrm{~kg} \cdot \mathrm{ha}^{-1}$ in $2001 \mathrm{and}^{1} 100 \mathrm{~kg} \cdot \mathrm{ha}^{-1}$ in 2002 . Stylo, in contrast, produced a maximum of $505 \mathrm{~kg} \cdot \mathrm{ha}^{-1}$ in 2001 and $40 \mathrm{~kg} \cdot \mathrm{ha}^{-1}$ in 2002. Plots of self-sown lespedeza emerged by late-March of 2002 and produced a maximum yield of $2330 \mathrm{~kg} \cdot \mathrm{ha}^{-1}$ by early July of 2002, contrasting with the sown lespedeza in this year, which did not achieve its maximum yield until the beginning of October. The seasonality of production of legume DM is summarized in Figure 4. In both years lespedeza was sub- 

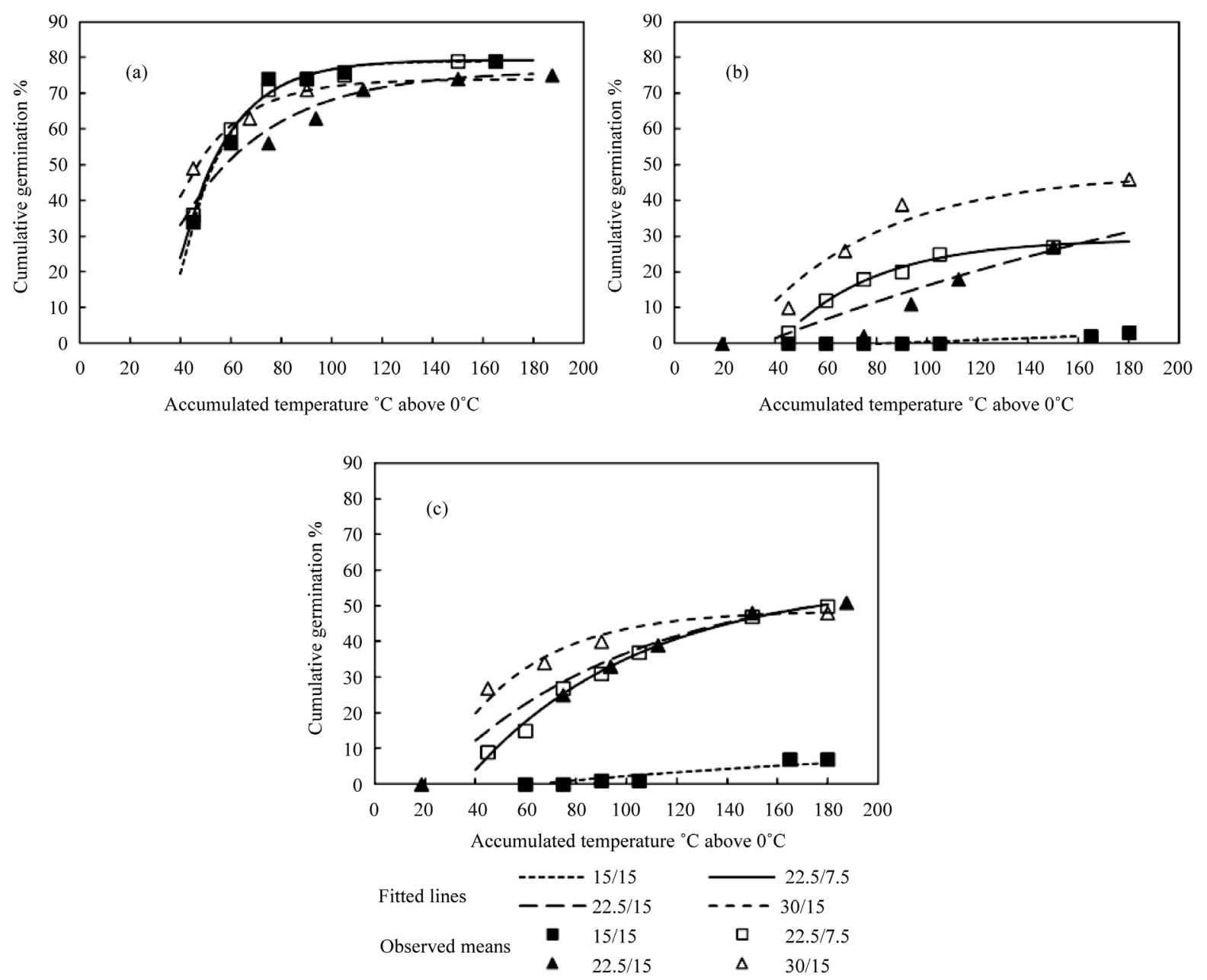

Figure 1. Effect of accumulated temperature and day/night temperature regimes [15.0/15.0, 22.5/7.5, 22.5/15.0 or 30.0/ $\left.15.0^{\circ} \mathrm{C}\right]$ on germination of lespedeza $(\mathrm{a})$, unhulled stylo (b) and hulled stylo (c).

ject to extensive leaf loss with end of season leaf deposition amounting to an average of $500 \mathrm{~kg} \cdot \mathrm{ha}^{-1}$ in 2001 and $625 \mathrm{~kg} \cdot \mathrm{ha}^{-1}$ in 2002. Despite tillage prior to sowing, by the end of the growing season regrowth of perennial warm season grass produced 280 and $630 \mathrm{~kg} \cdot \mathrm{ha}^{-1}$ under lespedeza and 700 and $1250 \mathrm{~kg} \cdot \mathrm{ha}^{-1}$ under stylo in 2001 and 2002, respectively.

\subsection{Self-Seeding by Lespedeza and Stylo}

Seed deposition by lespedeza following a single harvest during the first week of November in each year was 6680 seeds $\cdot \mathrm{m}^{-2}$ in 2001 and 3880 seeds $\cdot \mathrm{m}^{-2}$ in 2002. The corresponding stand counts of re-established lespedeza were $3225 \mathrm{pl} \cdot \mathrm{m}^{-2}$ in 2002 and $1030 \mathrm{pl} \cdot \mathrm{m}^{-2}$ in 2003. End-of-season seed deposition ranged from $2750 \mathrm{seed} \cdot \mathrm{m}^{-2}$ when forage was harvested in early July, to 260 seeds $\cdot \mathrm{m}^{-2}$ when forage was harvested in mid-September.

Self-sown lespedeza in 2002 deposited more than four times (9430 seeds $\cdot \mathrm{m}^{-2}$ ) the amount of seed produced by the crop sown in mid-April, probably reflecting both its longer growing season and greater biomass production, but there was ultimately no benefit in numbers of plants $\left(650 \mathrm{pl} \cdot \mathrm{m}^{-2}\right)$ established in the following season. Stylo seed deposition was 140 seeds $\cdot \mathrm{m}^{-2}$ in 2001, but in 2002 there was no measurable seed output.

\section{Discussion}

Temperature regime treatments focused on conditions expected during establishment of summer legumes in spring and early summer in the SGP. Restricted light-input treatments were intended to simulate the effect of 
Temperature $22.5 / 7.5^{\circ} \mathrm{C}$
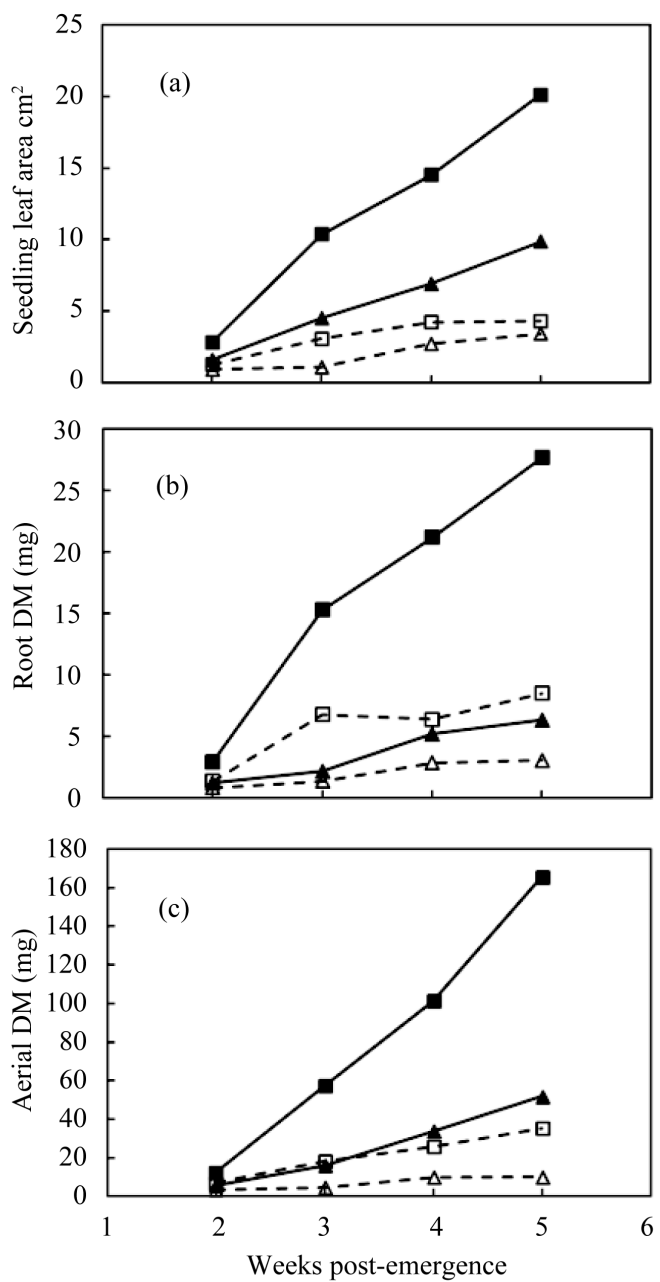

Weeks post-emergence
Temperature $30 / 15^{\circ} \mathrm{C}$

(d)

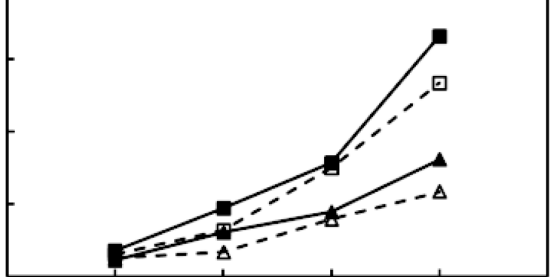

(e)
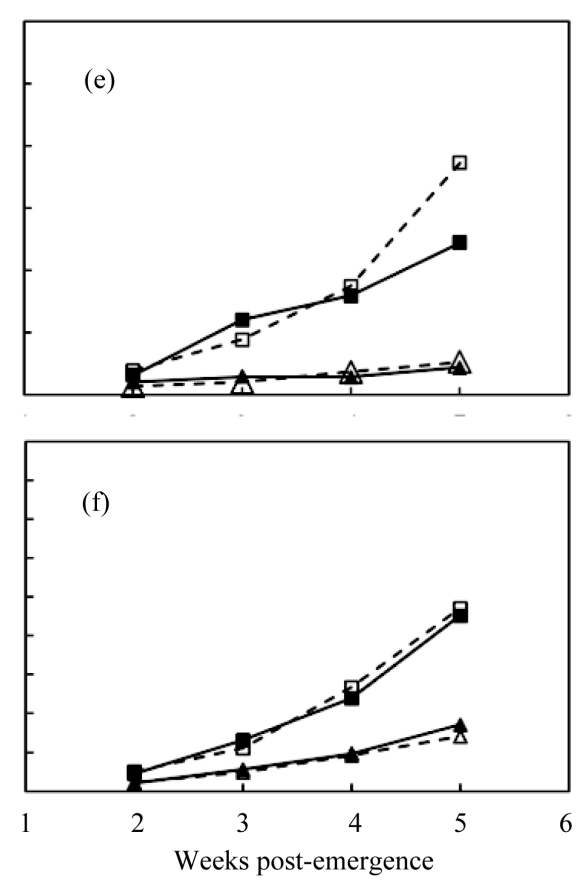

$\longrightarrow$ - LES FL

$--\Delta-$ STY SH

Figure 2. Temperature regime $\left[22.5 / 7.5\right.$ or $\left.30.0 / 15.0^{\circ} \mathrm{C}\right]$ and light input $\left[\mathrm{FL}=260 \mu \mathrm{E} \cdot \mathrm{m}^{2} \cdot \mathrm{sec}^{-1}\right.$ or SH $=90 \mu \mathrm{E} \cdot \mathrm{m}^{2} \cdot \mathrm{sec}^{-1}$ ] effects on seedling leaf area (a) (d); root DM (b) (e) and aerial DM (c) (f) of lespedeza and stylo in controlled environment. Least significant differences $(\mathrm{P}=0.05)$; Leaf area $=2.8$; Root DM = 4.7; Aerial DM = 20.5.

competition from an established canopy of warm-season grass on establishing warm-season legume.The germination and seedling growth responses to temperature of lespedeza and stylo show a clear contrast between the two species. At a given accumulated temperature lespedeza is able to germinate as well under a $15 / 15^{\circ} \mathrm{C}$ temperature regime as under $30 / 15^{\circ} \mathrm{C}$ day/night temperatures, while germination of stylo is clearly quite temperature-dependent over this range. The effect of lower temperature on germination rate appears also to be amplified by the presence of the stylo seed pod. Seedling growth responses to temperature show that, while lespedeza is suited for early-season establishment in the SGP (significantly extending the possible growing season for lespedeza in the SGP), stylo clearly is not and its poor low-temperature performance limits its effective growing season. The advantage of lespedeza over stylo is emphasized by long-term temperature data for the central SGP that show mean daily temperature exceeds $15^{\circ} \mathrm{C}$ for 168 days and $22.5^{\circ} \mathrm{C}$ for only 94 days each year.

Performance in the field reflected observations in controlled environment. Lespedeza can be a relatively productive crop when sown on tilled ground and its seed output, even following a mid-summer harvest, is sufficient for re-establishment by self-seeding. The ability of lespedeza to achieve early-season growth was amply demon- 

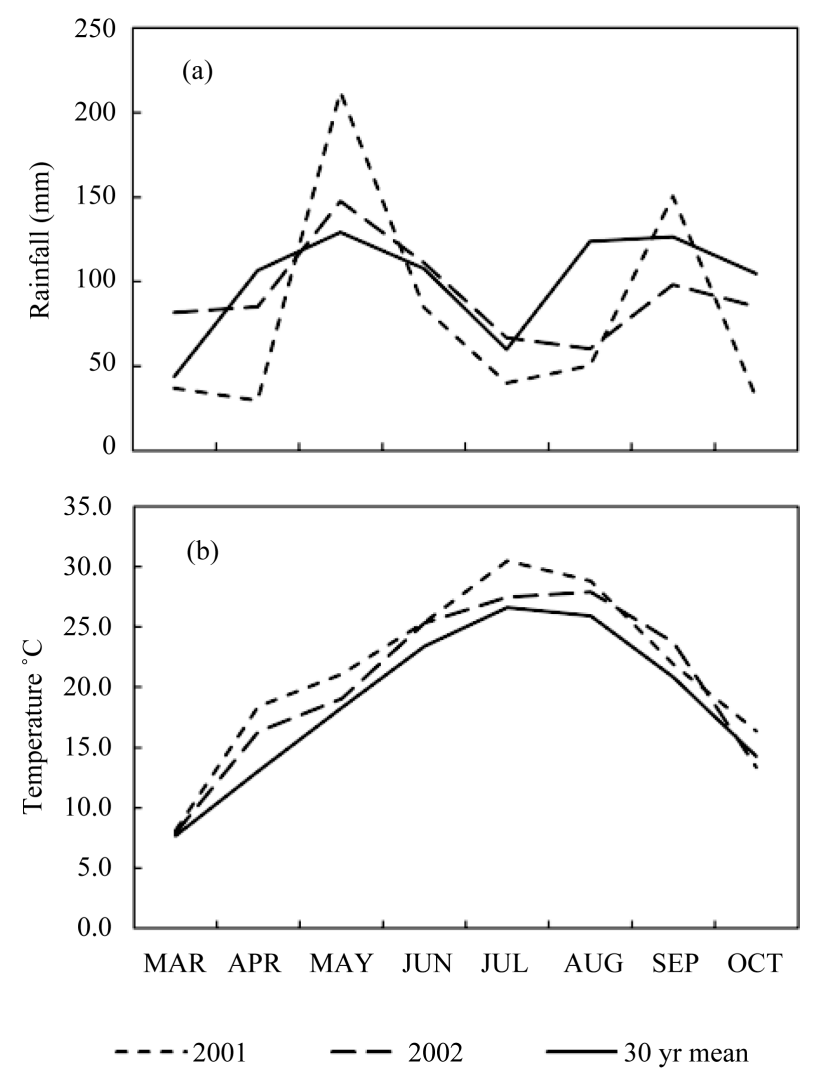

Figure 3. (a) Monthly rainfall totals and (b) mean daily temperatures ${ }^{\circ} \mathrm{C}$ for growing seasons of 2001, 2002. 30 yr-mean (1972-2001) values for each parameter are included for comparison with individual years.

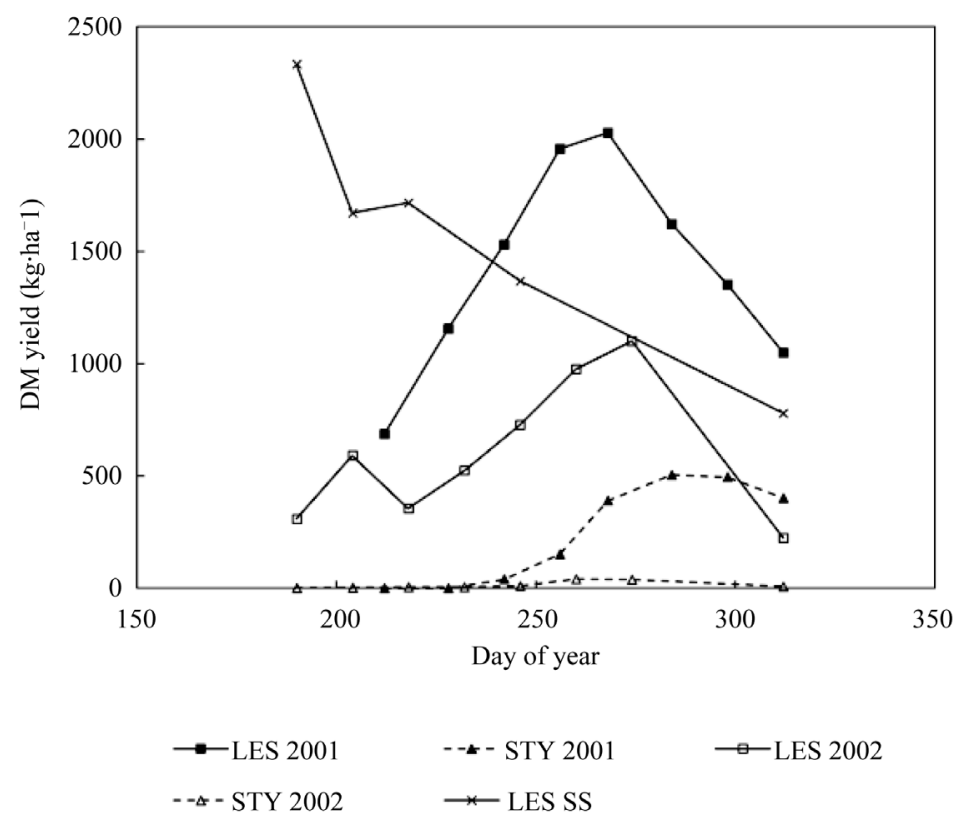

Figure 4. Seasonal distribution of forage DM yields of Lespedeza and Stylosanthes sown in 2001 or 2002, and harvested during the same year, or of Lespedeza self-sown (SS) at the end of the growing season of 2001 and harvested during 2002. Least significant differences $(\mathrm{P}=0.05) ; 2001=207 ; 2002=320$ and LES SS $(2002)=511$. 
strated by yields of the self-sown crop in 2002, but this capacity for early growth also exposes the crop to risk of damage by late frost. Although stylo produced seed in one year of the experiment it was an amount insufficient to re-establish the crop. Verano stylo therefore proved to be neither a productive forage nor a viable self-seeding crop in the SGP, and this conclusion is consistent with that of Edye [12] that S. hamata is not well adapted to environments outside $20^{\circ}$ latitude. The potential demonstrated by $S$. hamata at $30^{\circ} \mathrm{N}$ [10] is not sustained as far north as $35^{\circ}$, even though the central southern plains may meet precipitation and temperature requirements suggested by Edye et al., [12]. A potential alternative to $S$. hamata that merits investigation is the related S. biflora, which is native to the southern plains [2] and can persist in unimproved pastures.

\section{Acknowledgements}

The author gratefully acknowledges the valuable technical support provided by Kathie Wynn and Justin Cash throughout the implementation of these studies. This work was funded by the U.S. Department of Agriculture Agricultural Research Service (USDA-ARS). Mention of trademark names does not represent an endorsement over other comparable products by the USDA-ARS.

\section{References}

[1] Posler, G.L., Lenssen, A.W. and Fine, G.L. (1993) Forage Yield, Quality, Compatibility, Persistence of Warm-Season Grass-Legume Mixtures. Agronomy Journal, 85, 554-560. http://dx.doi.org/10.2134/agronj1993.00021962008500030007x

[2] Banta, M. and Thro, A.M. (1995) Agronomic Characterisation of Stylosanthes biflora. Tropical Grasslands, 29, 155162.

[3] Rao, S.C., Mayeux, H.S. and Northup, B.K. (2005) Performance of Forage Soybean in the Southern Great Plains. Crop Science, 45, 1973-1977. http://dx.doi.org/10.2135/cropsci2004.0598

[4] Rao, S.C. and Northup, B.K. (2008) Planting Date Affects Production and Quality of Grass Pea Forage. Crop Science, 48, 1629-1635. http://dx.doi.org/10.2135/cropsci2007.11.0622

[5] Beuselinck, P.R., Bouton, J.H., Lamp, W.O., Matches, A.G., McCaslin, M.H., Nelson, C.J., Rhodes, L.H., Sheaffer, C.C. and Volenec, J.J. (1994) Improving Legume Persistence in Forage Crop Systems. Journal of Production Agriculture, 7, 311-322. http://dx.doi.org/10.2134/jpa1994.0311

[6] Davis, D.K., McGraw, R.L. and Beuselinck, P.R. (1994) Herbage and Seed Production of Annual Lespedezas as Affected by Harvest Management. Agronomy Journal, 86, 704-706. http://dx.doi.org/10.2134/agronj1994.00021962008600040022x

[7] Bartholomew, P.W. and Williams, R.D. (2010) Overseeding Unimproved Warm-Season Pasture with Cool- and Warm-Season Legumes to Enhance Forage Productivity. Journal of Sustainable Agriculture, 34, 125-140. http://dx.doi.org/10.1080/10440040903482407

[8] Rao, S.C. and Phillips, W.A. (1999) Forage Production and Nutritive Value of Three Lespedeza Cultivars Intercropped into Continuous No-Till Winter Wheat. Journal of Production Agriculture, 12, 235-238. http://dx.doi.org/10.2134/jpa1999.0235

[9] Bayer, W. and Waters-Bayer, A. (1989) Adapting Tropical Pasture Research to the Production System: From Australian Ranching to African Pastoralism. Experimental Agriculture, 25, 277-289.

[10] Coelho, R.W., Mott, G.O., Ocumpaugh, W.R. and Brolmann, J.B. (1981) Agronomic Evaluation of Some Stylosanthes Species in North Florida, USA. Tropical Grasslands, 15, 31-37.

[11] Genstat (2008) Genstat for Windows, Release 11.1.0.1575. 11th Edition, VSN International Ltd., Oxford, UK.

[12] Edye, L.A. (1997) Commercial Development of Stylosanthes Pastures in Northern Australia. 1. Cultivar Development within Stylosanthes in Australia. Tropical Grasslands, 31, 503-508. 
Scientific Research Publishing (SCIRP) is one of the largest Open Access journal publishers. It is currently publishing more than 200 open access, online, peer-reviewed journals covering a wide range of academic disciplines. SCIRP serves the worldwide academic communities and contributes to the progress and application of science with its publication.

Other selected journals from SCIRP are listed as below. Submit your manuscript to us via either submit@scirp.org or Online Submission Portal.
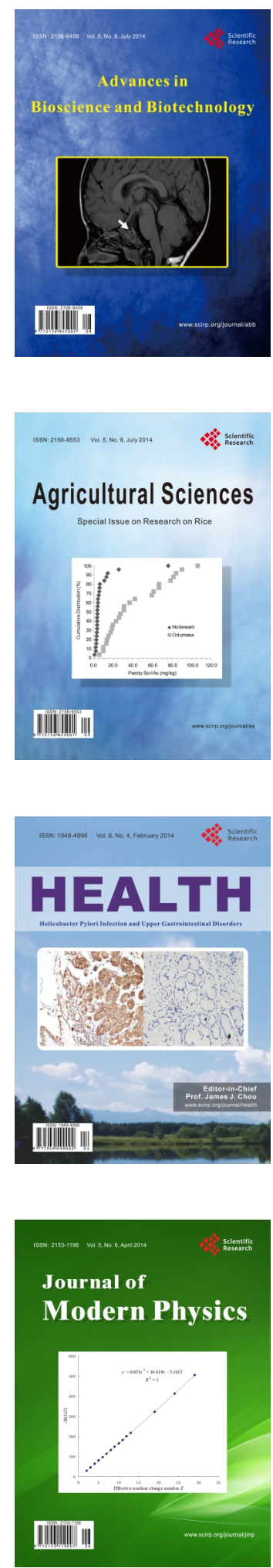
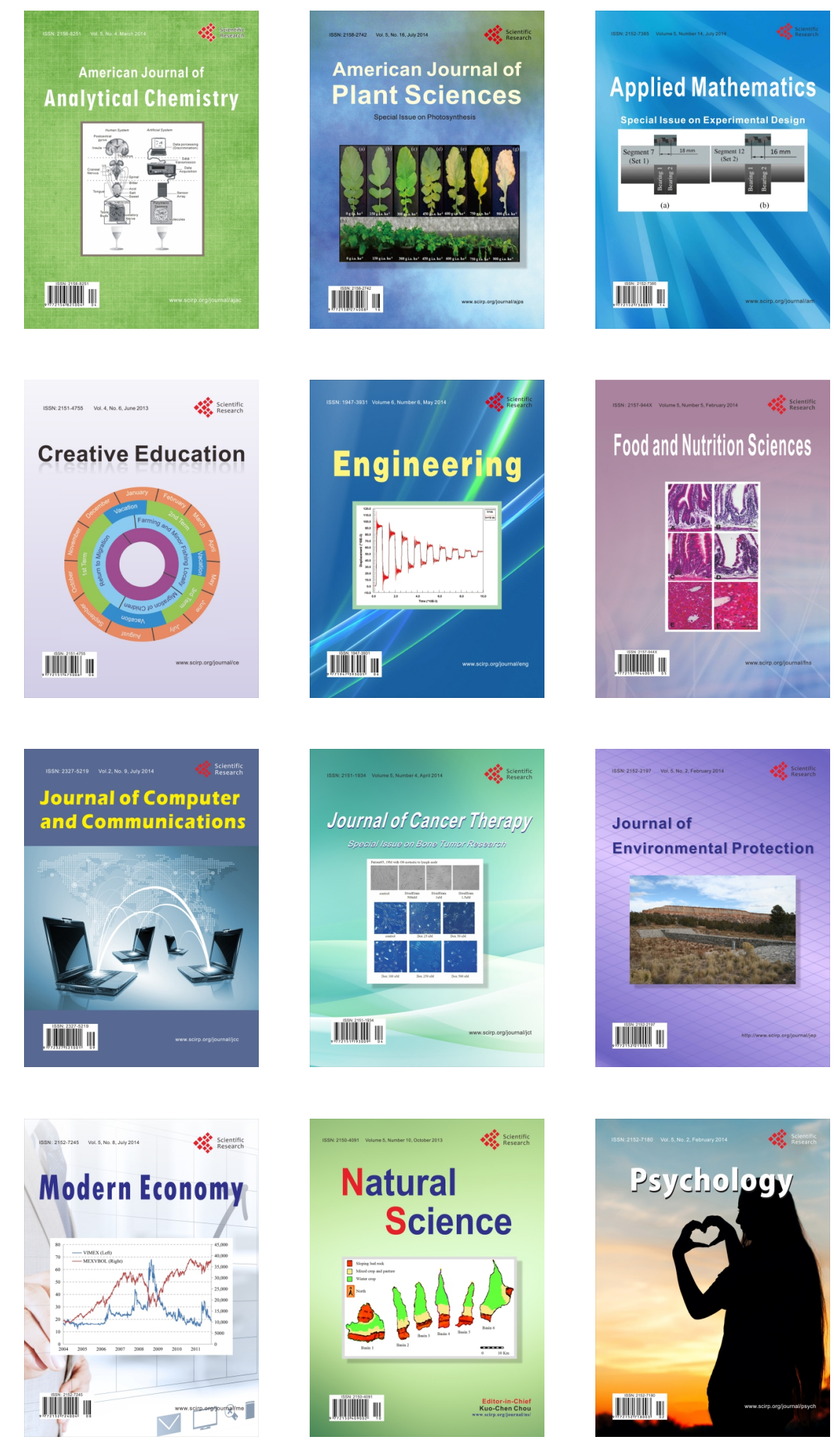